\title{
PENGARUH JENIS KEDELAI, WAKTU DAN SUHU PEMERAMAN TERHADAP KANDUNGAN PROTEIN TEMPE KEDELAI
}

\author{
Hanifah Mukhoyaroh \\ SMK Kesehatan Yaleka Merauke \\ Email:jurnal.florea@gmail.com \\ Diterima 12 Agustus 2015 disetujui 28 Oktober 2015
}

\begin{abstract}
Tempe is a traditional Indonesian food made by fermentation or fermentation using Rhizopus sp. Tempe is made from soybeans with high protein content. Tempeh-making process is influenced by several factors: temperature, humidity and curing time study aims to analyze the influence of soybeans, time, and temperature curing of the protein content of soybean tempe, as a biochemistry lab manual. The research method uses an experimental approach with three replications. Test material using a black and yellow soybeans type of treatment in this study is a type of soybean yellow and black, with a curing time of 18 hours and 36 hours, at a temperature of $100^{\circ} \mathrm{C}$ and $310^{\circ} \mathrm{C}$. The protein content was tested using formol. The results showed black soybean with a temperature of $100^{\circ} \mathrm{C}$ within 36 hours the highest protein content of $0.72 \%$. Low protein content of the black soybean with a curing temperature of $310^{\circ}$ C curing time of 36 hours.
\end{abstract}

Keywords: soybean, temperature, protein

\section{PENDAHULUAN}

Memasuki era globalisasi, Indonesia masih menghadapi masalah kurang gizi, yang disebabkan banyak faktor, salah satunya yaitu kurangnya persediaan makanan. Indonesia merupakan negara agraris yang memiliki hasil kedelai yang cukup tinggi, dengan bentuk olahan yang dikenal tempe, yaitu makanan tradisional yang telah lama di kenal di Indonesia, yang dibuat dengan cara fermentasi atau peragian menggunakan kapang Rhizopus sp. Tempe kaya akan protein sehingga keberadaannya dapat dijadikan alternatif sumber protein nabati yang terjangkau oleh berbagai lapisan masyarakat mengingat harga tempe yang relatif murah.

Tempe yang bermutu tinggi pasti mempunyai kandungan gizi yang tinggi seperti protein, lemak, karbohidrat, dan vitamin. Selain itu tempe menjadi lebih larut dalam air dan mudah dicerna dibanding kedelai. Hermana (1985) dalam Ginea Harvita (2007). Komposisi gizi tempe baik kadar protein, lemak dan karbohidratnya tidak banyak berubah dibandingkan kedelai. Protein, lemak, dan karbohidrat pada tempe menjadi lebih mudah dicerna di dalam tubuh dibandingkan dengan kedelai. Hal ini karena selama proses fermentasi terjadi penguraian dan penyederhanaan komponen-komponen yang terdapat pada kedelai menjadi lebih kecil dan sederhana. Perubahan tersebut dikatalisis oleh enzim yang diproduksi oleh kapang Hermanianto (1996) dalam Ginea Harvita (2007). Kandungan gizi utama yang terdapat pada tempe adalah protein yaitu sekitar $14,77 \%$ sampai $22,73 \%$. Tanuwidjaja (1995) dalam Ginea Harvita (2007). Kandungan gizi tempe tinggi, sangat bermanfaat untuk memenuhi kebutuhan protein melalui sumber protein nabati. Potensi tempe untuk meningkatkan kesehatan dan harganya yang relatif murah memberikan alternatif pilihan dalam pengadaan makanan bergizi yang terjangkau.

Proses pembuatan tempe dipengaruhi oleh beberapa faktor: suhu, kelembaban dan waktu pemeraman. Suhu pemeraman tempe yang baik digunakan untuk proses fermentasi adalah pada suhu kamar 20-37 $\mathrm{C}$ dengan kondisi tempat agak gelap, dan suhu maksimal $40^{\circ} \mathrm{C}$ karena apabila suhu terlalu tinggi pertumbuhan kapang tempe 
tidak akan sempurna. Selain suhu pemeraman dipengaruhi pula kelembaban, untuk mengkondisikan tempe. kelembaban dipengaruhi pula oleh lama pemeraman. lama pemeraman bervariasi dari 18-36 jam. Berdasarkan hasil penelitian Astuti (2003) dalam Erna (2010) menyatakan bahwa komposisi kedelai bervariasi tergantung varietas yang dikembangkan dan juga warna kulit maupun kotiledonnya. Kandungan protein dalam kedelai kuning bervariasi antara 31-48\%, dibandingkan dengan beras, jagung, tepung singkong, kacang hijau, daging, ikan segar, dan telur ayam, kedelai mempunyai kandungan protein lebih tinggi, hampir sama kadar protein susu skim kering. Berdasarkan hasil penelitian Ayu Rahadiyanti (2011) menunjukan bahwa rerata asupan protein kelompok perlakuan lebih tinggi sebesar $60,88 \pm 14,38$ dengan kandungan protein maksimal 81,3 dan asupan protein pada kelompok kontrol lebih rendah, sebesar $44,82 \pm 8,65$ dengan kandungan protein maksimal 54,58.

Suhu pemeraman tempe yang sering digunakan para perajin tempe adalah pada suhu $3^{\circ} \mathrm{C}$ yang menghasilkan tempe yang putih, kompak dan rasa serta aroma yang khas dan kuat. Tempe yang umum yang ada di Indonesia umumnya difermentasi pada suhu ruang yaitu sekitar $25^{\circ} \mathrm{C}$ selama 44-52 jam. Menurut Suprihatin (2010) kapang tempe dapat digolongkan kedalam mikroba yang bersifat mesofilik, yaitu dapat tumbuh baik pada suhu pemeraman $\left(25-27^{\circ} \mathrm{C}\right)$. Waktu pemeraman, suhu tempat pemeraman perlu diperhatikan, karena kedelai akan mengalami perubahan fisik maupun kimianya. Kapang protein kedelai akan diuraikan menjadi asam-asam amino, sehingga nitrogen terlarutnya akan mengalami peningkatan dan tempe menjadi lebih mudah dicerna. Kecepatan fermentasi ditentukan oleh temperatur inkubasi, inkubasi temperatur di bawah $40^{\circ} \mathrm{C}$ dan di atas $25^{\circ} \mathrm{C}$ tidak menghasilkan tempe yang baik. Suhu $37-38^{\circ} \mathrm{C}$ butuh waktu 22 jam untuk menghasilkan tempe yang baik, suhu $28-30^{\circ} \mathrm{C}$ perlu waktu 48 jam untuk menghasilkan tempe yang baik (Hedger,1982)

Fermentasi dapat diartikan sebagai perubahan gradual oleh enzim beberapa bakteri, khamir dan jamur. Contoh fermentasi adalah perubahan kimia dari fermentasi meliputi pengasaman susu, dekomposisi pati dan gula menjadi alkohol dan karbondioksida serta oksidasi senyawa nitrogen organic. (Hidayat, et al., 2006). Selama proses fermentasi pada pembutan tempe, kedelai akan mengalami perubahan fisik terutama tekstur, yang menjadi semakin lunak karena terjadi penurunan selulosa menjadi bentuk yang lebih sederhana. Hifa kapang juga mampu menembus permukaan kedelai sehingga dapat menggunakan nutrisi yang ada pada biji kedelai sehingga nilai gizi tempe lebih baik dari kacang kedelai. Perubahan fisik lainnya adalah peningkatan jumlah hifa kapang yang menyelubungi kedelai yang satu dengan yang lainnya menjadi satu kesatuan (Hidayat, et al., 2006). Berdasarkan penelitian yang dilakukan Istiqomah (2009), pada tahu kedelai menyatakan bahwa semakin lama fermentasi maka akan semakin besar kadar protein terlarutnya dan akan mencapai kondisi optimum pada fermentasi ke 72 jam kemudian mengalami penurunan pada hari berikutnya. Tujuan penelitian untuk mengkaji jenis kedelai, waktu dan suhu pemeraman terhadap kandungan protein tempe kedelai.

\section{METODE}

Penelitian menggunakan pendekatan eksperimen rancangan percobaan rancangan acak lengkap (RAL) 3 faktorial dan 3 kali ulangan. Faktor pertama adalah jenis kedelai, faktor kedua adalah lama pemeraman dan faktor yang ketiga adalah suhu pemeraman. Alat dan bahan yang digunakanyaitu: tampah besar, ember, keranjang, rak bambu, cetakan, pengaduk 
kayu, dandang, karung goni, tungku atau kompor dan daun pisang atau plastik, kedelai, ragi tempe dan air secukupnya.

Prosedur pembuatan tempe: kedelai dimasukkan dalam ember berisi air. Setelah semua terendam air, ember diangkat dan dimiringkan sedikit demi sedikit di atas bak untuk menuang kedelai yang terbawa aliran air, kedelai yang telah bersih direndam dalam air bersih selama satu malam (12 jam) untuk memudahkan pengulitan kulit biji kedelai. Pagi hari air rendaman dibuang kemudian biji kedelai dicuci selanjutnya direbus sekitar 1 jam sehingga diperoleh kedelai setengah matang kemudian diangkat, ditiriskan dan didinginkan. Selanjutnya, kedelai dicuci dengan cara diinjak-injak sampai seluruh kulit bijinya pecah-pecah dan dipisahkan kulit dan kedelainya. Kedelai direbus lagi sekitar 30 menit, setelah matang, kedelai diangkat, ditiriskan dan ditebar pada tampah, setelah dingin kemudian dicampurkan ragi tempe sebanyak 100 gram dan dibungkus.

Alat, Bahan untuk uji protein Alat yang digunakan: neraca analitik, erlenmeyer, pipet ukur, pipet volumetrik, buret, ekstrak tempe, K-oksalat jenuh, phenolphtalein $1 \% \mathrm{NaOH} 0,1 \mathrm{~N}$, warna standart (larutan tempe + air +K-oksalat jenuh + resinulin $\mathrm{HCl}$ ), formaldehida $40 \%$, air suling dan Indikator. Prosedur uji protein menggunakan titrasi formol yaitu: memindahkan $10 \mathrm{ml}$ larutan ekstrak tempe ke dalam erlenmeyer dan menambahkan air suling 0,4 ml dan larutan K-oksalat jenuh serta $1 \mathrm{ml}$ kemudian phenolphtalein $1 \%$, diamkan selama 2 menit, titrasi larutan ekstrak tempe dengan $0,1 \mathrm{~N} \mathrm{NaOH}$ sampai mencapai warna standar (merah jambu), Setelah warna tercapai, tambah $2 \mathrm{ml}$ formaldehida $40 \%$, teruskan titrasi dengan larutan $\mathrm{NaOH} 0,1 \mathrm{~N}$ sampai tercapai warna standar lagi, membuat larutan blanko yaitu: $20 \mathrm{ml}$ air suling ditambah $0,4 \mathrm{ml}$ larutan $\mathrm{K}$ oksalat dan $1 \mathrm{ml}$ indikator phenolphtalein dan 2,0 $\mathrm{ml}$ formaldehida dan titrasi lagi dengan larutan $\mathrm{NaOH} 0,1 \mathrm{~N}$, hasil titrasi terkoreksi, yaitu hasil titrasi kedua dikurangi dengan hasil titrasi blanko merupakan hasil titrasi formol.

Analisis data menggunakan analisis deskriptif untuk penghitungan kadar protein serta analisis one way-ANOVA SPSS versi 19 dan dilanjutkan dengan uji lanjut BNT/LSD.

\section{HASIL DAN PEMBAHASAN}

Hasil penghitungan akumulasi data kadar protein dihitung berdasarkan hasil titrasi larutan sampel dinyatakan dalam bentuk presentase $(\%)$. Kadar protein pada 8 perlakuan dilihat dari hasil titrasi melalui skala biuret kemudian dihitung menggunakan perhitungan manual dapat dilihat pada Tabel 1

Tabel 1 Data Rata-rata Hasil Pengamatan Jenis Kedelai, Lama Dan Suhu Pemeraman Terhadap Ulangan Pengujian Kadar Protein.

\begin{tabular}{ccccc}
\hline & \multicolumn{2}{l}{ Kandungan protein $/ 100 \mathrm{~g}$} & $\begin{array}{l}\text { Rata- } \\
\text { rata } \\
\text { Perlakuan }\end{array}$ \\
\cline { 2 - 5 } & $\mathrm{U}_{1}$ & $\mathrm{U}_{2}$ & $\mathrm{U}_{3}$ & $\begin{array}{l}\text { kadar } \\
\text { protein } \\
(\%)\end{array}$ \\
\hline $\mathrm{J}_{1} \mathrm{~L}_{1} \mathrm{~S}_{1}$ & 0,0483 & 0,0322 & 0,0402 & 0,04 \\
$\mathrm{~J}_{1} \mathrm{~L}_{1} \mathrm{~S}_{2}$ & 0,0407 & 0,0407 & 0,0322 & 0,03 \\
$\mathrm{~J}_{1} \mathrm{~L}_{2} \mathrm{~S}_{1}$ & 0,0322 & 0,0322 & 0,0245 & 0,02 \\
$\mathrm{~J}_{1} \mathrm{~L}_{2} \mathrm{~S}_{2}$ & 0,1448 & 0,1533 & 0,1360 & 0,14 \\
$\mathrm{~J}_{2} \mathrm{~L}_{1} \mathrm{~S}_{1}$ & 0,0407 & 0,483 & 0,0322 & 0,04 \\
$\mathrm{~J}_{2} \mathrm{~L}_{1} \mathrm{~S}_{2}$ & 0,1770 & 0,1694 & 0,1855 & 0,17 \\
$\mathrm{~J}_{2} \mathrm{~L}_{2} \mathrm{~S}_{1}$ & 0,2499 & 0,2499 & 0,2252 & 0,72 \\
$\mathrm{~J}_{2} \mathrm{~L}_{2} \mathrm{~S}_{2}$ & 0,0085 & 0,0085 & 0,0160 & 0,01 \\
\hline
\end{tabular}

Keterangan:

$\mathrm{J}_{1} \mathrm{~L}_{1} \mathrm{~S}_{1}=$ jenis kedelai kuning, lama 18 jam, suhu pemeraman $10^{\circ} \mathrm{C}$

$\mathrm{J}_{1} \mathrm{~L}_{1} \mathrm{~S}_{2}=$ jenis kedelai kuning, lama 18 jam, suhu pemeraman $31^{\circ} \mathrm{C}$

$\mathrm{J}_{1} \mathrm{~L}_{2} \mathrm{~S}_{1}=$ jenis kedelai kuning, lama 36 jam, suhu pemeraman $10^{\circ} \mathrm{C}$

$\mathrm{J}_{1} \mathrm{~L}_{2} \mathrm{~S}_{2}=$ jenis kedelai kuning, lama 36 jam, suhu pemeraman $31^{\circ} \mathrm{C}$

$\mathrm{J}_{2} \mathrm{~L}_{1} \mathrm{~S}_{1}=$ jenis kedelai hitam, lama 18 jam, suhu pemeraman $10^{\circ} \mathrm{C}$

$\mathrm{J}_{2} \mathrm{~L}_{1} \mathrm{~S}_{2}=$ jenis kedelai hitam, lama 18 jam, suhu pemeraman $31^{\circ} \mathrm{C}$

$\mathrm{J}_{2} \mathrm{~L}_{2} \mathrm{~S}_{1}=$ jenis kedelai hitam, lama 36 jam, suhu pemeraman $10^{\circ} \mathrm{C}$

$\mathrm{J}_{2} \mathrm{~L}_{2} \mathrm{~S}_{2}=$ jenis kedelai hitam, lama 36 jam, suhu pemeraman $31^{\circ} \mathrm{C}$ 
Tabel 1 menunjukkan ada perlakuan jenis kedelai hitam, lama pemeraman 36 jam dan suhu $10^{0} \mathrm{C}\left(\mathrm{J}_{2} \mathrm{~L}_{2} \mathrm{~S}_{1}\right)$ memiliki kadar protein tertinggi yaitu sebesar $0,72 \%$ dan kadar protein terendah terdapat pada perlakuan jenis kedelai hitam, lama pemeraman 36 jam dan suhu pemeraman $31^{0} \mathrm{C}\left(\mathrm{J}_{2} \mathrm{~L}_{2} \mathrm{~S}_{2}\right)$ menunjukkan kadar sebesar $0,01 \%$.

Uji lanjut LSD yang menunjukan signifikansi perbedaan nyata adalah kombinasi perlakuan kedelai hitam, lama pemeraman 36 jam suhu pemeraman $10^{\circ} \mathrm{C}$ $\left(\mathrm{J}_{2} \mathrm{~L}_{2} \mathrm{~S}_{1}\right)$ dengan kedelai hitam, lama pemeraman 36 jam, suhu pemeraman $31{ }^{0} \mathrm{C}$ $\left(\mathrm{J}_{2} \mathrm{~L}_{2} \mathrm{~S}_{2}\right)$ dengan angka signifikasi sebesar 0,23067 . Penggunaan jenis kedelai, lama dan suhu pemeraman mempengaruhi kadar protein tempe kedelai. Hasil penelitian menunjukkan bahwa jenis kedelai, lama dan suhu pemeraman berpengaruh nyata terhadap kandungan protein tempe kedelai. Adapun gambar rata-rata kadar protein yang dihasilkan pada perlakuan berbeda disajikan dalam Gambar 1.

Tabel 1 menunjukkan bahwa kadar protein tempe kedelai tertinggi terdapat pada jenis kedelai hitam, lama pemeraman 36 jam dan suhu pemeraman $10^{0} \mathrm{C}\left(\mathrm{J}_{2} \mathrm{~L}_{2} \mathrm{~S}_{1}\right)$ karena kapang sudah merombak enzimenzim senyawa kompleks menjadi senyawa sederhana yang mendekati titik optimum (72 jam) dan suhu yang tepat untuk kapang tumbuh. Suhu tinggi akan membuat kapang tidak bisa tumbuh sempurna.

Tempe adalah makanan yang dibuat dari fermentasi dengan menggunakan beberapa jenis kapang (Rhizopus sp). Jamur yang tumbuh pada kedelei tersebut menghasilkan enzim-enzim yang mampu merombak senyawa organik kompleks menjadi senyawa yang lebih sederhana sehingga senyawa tersebut dengan mudah digunakan oleh tubuh. Rhizopus sp tumbuh baik pada kisaran $\mathrm{pH}$ 3,4-6, semakin lama waktu pemeraman, $\mathrm{pH}$ tempe semakin

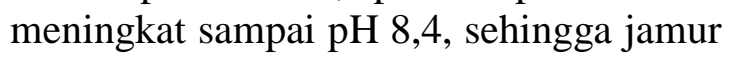

semakin menurun karena $\mathrm{pH}$ tinggi kurang sesuai untuk pertumbuhan jamur.

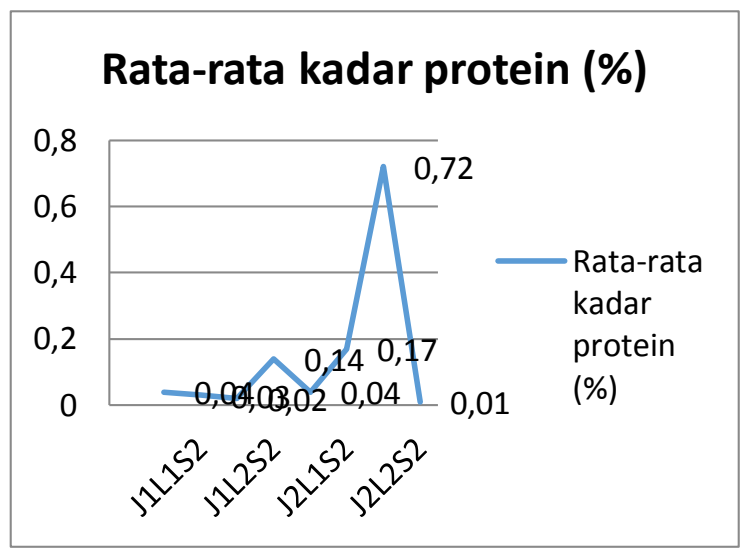

Gambar 1 Grafik Rata-rata Hasil Pengamatan Jenis Kedelai, Lama Dan Suhu Pemeraman Terhadap Ulangan Pengujian Kadar Protein.

Jamur membutuhkan air untuk pertumbuhannya tetapi kebutuhan air pada jamur lebih sedikit dari pada bakteri. Rhizopus oligosporus menghasilkan enzim-enzim protase. Perombakan senyawa kompleks protein menjadi senyawa-senyawa yang lebih sederhana adalah penting dalam pemeraman tempe, dan merupakan salah satu faktor utama penentu kualitas tempe, yaitu sebagai sumber protein nabati yang memiliki nilai cerna yang amat tinggi.

Menurut penelitian Istiqomah (2009) menyatakan bahwa semakin lama pemeraman maka akan semakin besar kadar protein terlarutnya dan akan mencapai kondisi optimum pada pemeraman ke 72 jam kemudian mengalami penurunan pada hari berikutnya. Semakin lama pemeraman maka akan semakin besar aktifitas enzim tripsinnya dan akan mencapai kondisi optimum pada pemeraman ke 72 jam akan mengalami penurunan pada hari berikutnya.

Suhu pemeraman dalam pembuatan tempe harus diatur karena bila suhu pemeraman terlalu tinggi akan menyebabkan pertumbuhan kapang tidak 
sempurna, Suhu pemeraman yang tinggi akan menghasilkan tempe terlalu basah, tempe berbau amoniak atau alkohol dan tempe kepanasan atau (overheating). Suhu pemeraman rendah akan menghambat pertumbuhan kapang Syarief et al., (1999) dalam Wisnu Cahyadi (2007).

Kadar protein tempe kedelai cenderung mengalami kenaikan dengan meningkatnya waktu pemeraman. Melalui proses pemeraman, senyawa-senyawa komplek pada kedelai dicerna oleh kapang dengan reaksi enzimatis dan menghasilkan senyawa-senyawa yang lebih sederhana. Selama proses pemeraman terjadi perubahan jumlah kandungan asam-asam amino yang secara keseluruhan jumlah asam-asam amino mengalami kenaikan setelah proses pemeraman. Jenis kedelai yang digunakan dalam pembuatan tempe kedelai dianjurkan untuk menggunakan jenis kedelai kuning, karena kulit ari kedelai kuning tidak terlalu kelihatan sehinggga hasil tempe terlihat bersih dan menarik.

\section{SIMPULAN}

Berdasarkan hasil penelitian dapat ditarik kesimpulan bahwa lama pemeraman dan suhu pemeraman berpengaruh terhadap kadar protein, hal ini disebabkan karena kapang tidak dapat tumbuh kemudian mati yang ditunjukkan dengan perubahan fisik pada tempe, tempe menjadi hitam dan terjadi denaturasi protein. Penelitian ini mengkaji tentang pengaruh jenis kedelai, lama dan suhu pemeraman terhadap kandungan protein pada tempe saja sehingga masih perlu adanya pengembangan penelitian. Penelitian dapat dilanjutkan untuk mengkaji nilai gizi terhadap tempe pada perbedaan suhu pemeraman, waktu pemeraman dan jenis tempe, sehingga dapat memberikan informasi kepada masyarakat secara lebih akurat.

\section{DAFTAR PUSTAKA}

Ayu Rahadiyanti. (2011). Pengaruh Tempe Kedelai Terhadap Kadar Glukosa Darah Pada Prediabetes. Semarang: Program Studi Ilmu Gizi Universitas Diponegoro.

Ginea Harvita. (2007). Identifikasi Kinerja Industri Kecil Tempe Di Pulau Jawa dan Lampung. Bogor: Fakultas Teknologi Pertanian Institut Pertanian Bogor.

Hidayat. (2006). Mengetahui perbedaan karakteristik genetik beberapa varietas kedelai hitam. Sumatra: Universitas Sumatra Utara.

Istiqomah. (2009). Pengaruh Waktu Fermentasi Limbah Padat Tahu Terhadap Kadar Protein dan Aktivitas Enzim Tripsin. Yogyakarta: Program Studi Kimia UIN Sunan Kalijaga.

Hedger.(1982). Produksi Tempe Fermentasi Makanan Indonesia.Wales: Departement of Botany and Microbiology University Collage of Wales

Suprihatin. (2010). Teknologi Perpindahan Massa dalam Perancangan Proses Reaksi. Surabaya: Universitas Negeri Surabaya

Sugiono. (2011). Metode Penelitian Pendidikan (Pendekatan Kuantitatif, Kualitatif, dan R \& D). Bandung: Alfa beta.

Wisnu Cahyadi. 2007. Kedelai Khasiat dan Teknologi. Jakarta: PT Bumi Aksara 